\title{
Samsonia erythrinae gen. nov., sp. nov., isolated from bark necrotic lesions of Erythrina sp., and discrimination of plant-pathogenic Enterobacteriaceae by phenotypic features
}

\author{
1 UMR de Pathologie \\ Végétale INRA-INH- \\ Université, 42 rue Georges \\ Morel, BP 57, F-49071 \\ Beaucouzé Cedex, France \\ 2 ESA 7076, Université Pierre \\ et Marie Curie et CNRS, \\ Observatoire \\ Océanologique, Station \\ Zoologique, F-06230, \\ Villefranche-sur-mer, \\ France \\ 3 INSERM CJF 96.06, Faculté \\ de Médecine, 27 boulevard \\ Jean Moulin, F-13385 \\ Marseille Cedex 05, France
}

\author{
Laurent Sutra, ${ }^{1}$ Richard Christen, ${ }^{2}$ Claude Bollet, ${ }^{3}$ Philippe Simoneau ${ }^{1}$ \\ and Louis Gardan ${ }^{1}$
}

Author for correspondence: Laurent Sutra. Tel: +332412257 29. Fax: +33241225705. e-mail: sutra@angers.inra.fr

\begin{abstract}
Bacterial strains isolated from diseased erythrina (Erythrina sp.) trees in Martinique (French West Indies) were studied using phenotypic tests, 16S rDNA sequence analysis and DNA-DNA hybridization. Numerical analysis of phenotypic characteristics showed that these strains formed an homogeneous phenon among plant-pathogenic Enterobacteriaceae, and gave useful and updated information for the identification of these bacteria. Results of DNA-DNA hybridization indicated that strains from erythrina belonged to a discrete genomospecies (89-100\% hybridization) and had low levels of DNA relatedness (2-33\% hybridization) with reference strains of phytopathogenic Erwinia, Brenneria, Pectobacterium, Pantoea and Enterobacter species. 165 rDNA sequence analysis using three different methods revealed that the position of strain CFBP ${ }^{5236^{\mathrm{T}}}$ isolated from erythrina was variable in the different trees, so that strains from erythrina could not be assigned to any recognized genus. It is proposed that these strains are included in a new genus, Samsonia. The name Samsonia erythrinae is proposed for the new species. The $\mathrm{G}+\mathrm{C}$ content of the DNA of the type strain, CFBP 5236 (= ICMP 13937'), is $57.0 \mathrm{~mol} \%$.
\end{abstract}

Keywords: Samsonia erythrinae gen. nov., sp. nov., Erythrina, plant-pathogenic Enterobacteriaceae, 16S rDNA sequence analysis, DNA-DNA hybridization

\section{INTRODUCTION}

A bacterial disease of trees of erythrina (Erythrina sp.) used as windbreaks around banana plantations was observed in Martinique (French West Indies) in 1995 (Sutra et al., 1999). This disease was characterized by defoliation of the main branches of trees and browning of large areas of the bark surface, which girdled the base of defoliated branches. Removal of the superficial layer of the bark revealed brown, water-soaked necrotic lesions of the deeper layers of the bark and of the cambium, exhaling a nasty smell. All these symptoms suggested that the causal agent of the disease was different from Xanthomonas axonopodis pv. erythrinae which caused exclusively a leaf spot

The GenBank accession number for the $16 \mathrm{~S}$ rRNA gene sequence of strain CFBP $5236^{\top}$ is AF273037. disease on erythrina in India (Patel et al., 1952). Bacterial strains were isolated as nearly pure cultures from natural necrotic lesions of different diseased erythrina trees. All isolated strains had the general characteristics of the family Enterobacteriaceae. The fact that they were $\beta$-galactosidase-positive, argininedihydrolase-, lysine- and ornithine-decarboxylasenegative, produced acetoin and were weakly pectolytic (Sutra et al., 1999) suggested that these bacteria belong to the genus Erwinia or to one of the related genera recently proposed by Hauben et al. (1998). A preliminary study based on a limited number of phenotypic characteristics and on pathogenicity tests showed that strains isolated from erythrina trees were phenotypically related to, but different from, Pectobacterium carotovorum subsp. betavasculorum and subsp. wasabiae, and that they were pathogenic when inoculated to erythrina cuttings (Sutra et al., 1999). All these 
results suggested that bacteria isolated from diseased erythrina trees constitute a novel taxon within the plant-pathogenic Enterobacteriaceae.

The aim of the present study was to determine the taxonomic status of these bacteria by comparison with reference strains of previously described plantpathogenic species of Enterobacteriaceae on the basis of numerical analysis of phenotypic characteristics, DNA-DNA hybridizations and sequence analyses of 16S rRNA genes. According to our results, we propose that the strains isolated from diseased erythrina trees are included in a new genus, Samsonia gen. nov., and in a new species, Samsonia erythrinae sp. nov. Moreover, additional information is given for the identification of plant-pathogenic species of the family Enterobacteriaceae based on the phenotypic features of reference and type strains.

\section{METHODS}

Bacterial strains. Five strains (CFBP 5236 ${ }^{\mathrm{T}}$-CFBP 5240) were isolated from necrotic lesions of erythrina from two locations in Martinique (French West Indies) (Sutra et al., 1999). Thirty-six type and reference strains of Brenneria, Enterobacter, Erwinia, Pantoea and Pectobacterium plantpathogenic species were used for comparisons in numerical analysis of phenotypic data and DNA-DNA hybridizations. All reference strains were obtained from the Collection Française de Bactéries Phytopathogènes (CFBP, Angers, France) and are designated according to the present nomenclature of plant-pathogenic Enterobacteriaceae (Young et al., 1996; Hauben et al., 1998) (Fig. 1 and Table 3). Strains were cultured routinely on YBGA (yeast extract, $7 \mathrm{~g}$; bactopeptone, $7 \mathrm{~g}$; glucose, $7 \mathrm{~g}$; agar, $15 \mathrm{~g}$; distilled water, $1000 \mathrm{ml} ; \mathrm{pH} \mathrm{7.2)}$ and incubated at $28^{\circ} \mathrm{C}$.

Phenotypic tests. Twenty-two conventional biochemical and physiological tests were used. Hydrolysis of gelatin, lecithin and casein was tested on gelatin agar, on egg-yolk agar and on skimmed-milk agar, respectively (Smibert \& Krieg, 1994). Acid production from inulin in phenol red peptone water, production of reducing substances from sucrose, malonate utilization, indole production from tryptophan, anaerobic degradation of arginine (Moeller medium) and utilization of citrate as sole carbon source (Simmons' medium) were studied using previously described methods (Ngwira \& Samson, 1990; Gallois et al., 1992). Liquefaction of calcium polygalacturonate was tested in Sutton's medium modified after Bonnet (1973). Utilization of D-( -$)$-tartrate and acid production from $\alpha$-methyl glucoside, D- $(+)$-arabitol, D(-)-arabinose, lactose, mannitol, melibiose, raffinose and sorbitol were tested on the basal medium of Ayers et al. (1919) supplemented with $0 \cdot 1 \%(\mathrm{w} / \mathrm{v})$ organic acid sodium salt or sugar. All these tests were incubated at $28{ }^{\circ} \mathrm{C}$ for $15 \mathrm{~d}$. Strains were also investigated for their ability to grow at 36 and $39^{\circ} \mathrm{C}$ in King B broth, and at $25^{\circ} \mathrm{C}$ in yeast peptone broth containing $5 \%$ sodium chloride. In addition, strains were tested for the assimilation of 99 organic substrates using commercial Biotype 100 strips (bioMérieux). Strips were inoculated as recommended by the manufacturer and results were read visually after 2,3 and $4 \mathrm{~d}$ incubation at $28^{\circ} \mathrm{C}$.

Numerical taxonomy. A total of 121 characteristics (22 conventional tests and assimilation of 99 organic substrates) were included in the numerical taxonomy analysis. The distance matrix was calculated using the Jaccard coefficient (Sneath \& Sokal, 1973). Cluster analysis was done by using the unweighted pair group method with arithmetic averages (UPGMA) (Sneath \& Sokal, 1973). At a chosen level of phenotypic distance, the amount of information for each test was measured by calculating the diagnostic ability coefficient (Descamps \& Véron, 1981) to determine the discriminating biochemical characteristics of the strains clustered in the different phenons and of unclustered strains.

Sequencing of $16 \mathrm{~S}$ rDNA and phylogenetic analyses. Extraction of DNA from strain CFBP $5236^{\mathrm{T}}$ was carried out by using a QIAmp kit (Qiagen). PCR-mediated amplification of the $16 \mathrm{~S}$ rDNA of strain CFBP $5236^{\mathrm{T}}$ and sequence determination were performed as previously described (Weisburg et al., 1991). The 16S rDNA sequence obtained for strain CFBP $5236^{\mathrm{T}}$ was aligned manually by reference to a database of about 10000 already aligned bacterial 16S rDNA sequences. Phylogenetic trees were constructed using three different methods: neighbour-joining (bioNJ), maximum-likelihood and maximum-parsimony. Only sites that had no obvious homoplasy were used for these analyses (positions 89-451, 475-1001, 1006-1128, 1133-1388 of the $16 \mathrm{~S}$ rDNA sequence of strain CFBP $5236^{\mathrm{T}}$ ). For the bioNJ analysis, a distance matrix was calculated according to the Kimura two-parameters correction. The results of bioNJ analysis were evaluated with bootstrap using 500 replications. BioNJ analysis was performed according to Gascuel (1997), maximum-likelihood data (options QFYG) were obtained using the fastDNAml program of G. J. Olsen (University of Illinois, Urbana, USA) and maximumparsimony analysis was performed using PHYLIP (Phylogeny Inference Package, version $3.573 \mathrm{c}$, distributed by $\mathbf{J}$. Felsenstein, University of Washington, Seattle, USA). The phylogenetic trees were drawn using NJPLOT (Perrière \& Gouy, 1996) and MacDRAW software for the Apple Macintosh.

DNA extraction and DNA-DNA hybridization. Extraction and purification of DNA were performed as described by Brenner et al. (1982). Native DNAs of strains CFBP 5236 and CFBP 5237 were labelled in vitro with tritium-labelled nucleotides by random-priming (Feinberg \& Vogelstein, 1983) using a Megaprime kit (Amersham). The S1 nuclease/ trichloracetic acid method was used for DNA-DNA hybridizations (Croza et al., 1973; Grimont et al., 1980). The reassociation was performed at $60^{\circ} \mathrm{C}$ in $0.42 \mathrm{M} \mathrm{NaCl}$. The strains used in DNA-DNA hybridizations are listed in Table 3.

DNA base composition. The $\mathrm{G}+\mathrm{C}$ contents of strains CFBP $5236^{\mathrm{T}}$ and CFBP 5237 were determined by the thermal denaturation temperature (Mamur \& Doty, 1962) and were calculated by using the equation of Owen \& Lapage (1976). Escherichia strain K12 CIP 54-117 (DNA G + C content of $50.6 \mathrm{~mol} \%$ ) was used as control.

\section{RESULTS AND DISCUSSION}

\section{Numerical analysis of phenotypic characteristics}

A preliminary study based on 48 phenotypic tests suggested that strains isolated from diseased erythrina trees in Martinique (French West Indies) constituted an original phenotypic group within the plantpathogenic Enterobacteriaceae (Sutra et al., 1999). A more complete analysis of 121 phenotypic characteristics performed on these strains in comparison with type 


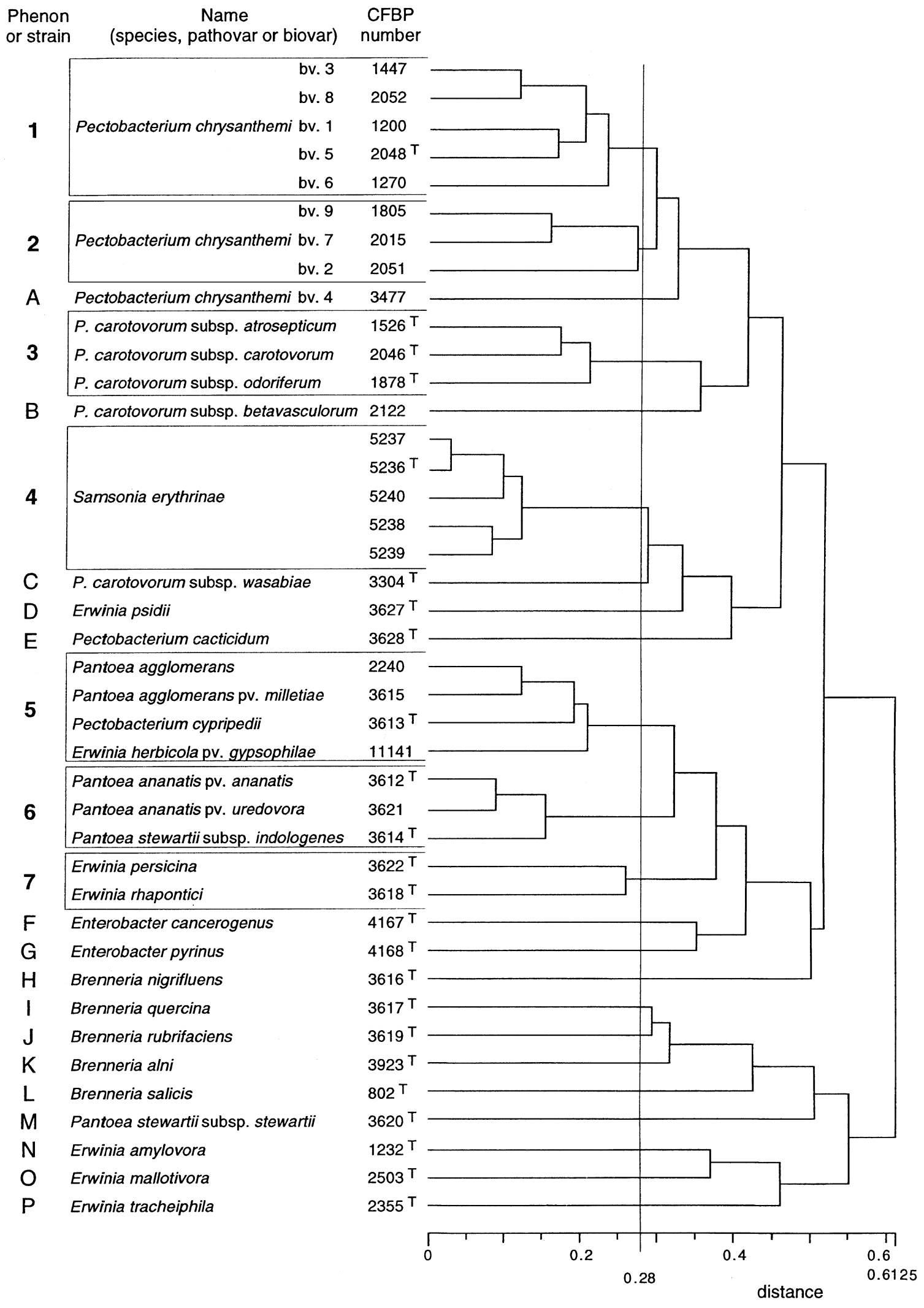

Fig. 1. Dendrogram of phenotypic distances between the 41 strains of plant-pathogenic Enterobacteriacae included in this study. CFBP, Collection Française de Bactéries Phytopathogènes, Angers, France; P., Pectobacterium. 
Table 1. Biochemical characteristics that differentiate Samsonia erythrinae strains (phenon 4) from other plantpathogenic Enterobacteriaceae

+ , Positive; -, negative; numbers correspond to the percentage of positive strains.

\begin{tabular}{|c|c|c|c|c|c|c|c|c|c|c|c|c|c|c|c|c|c|c|c|c|c|c|c|}
\hline \multirow[t]{2}{*}{ Characteristic } & \multicolumn{7}{|c|}{ Phenon no.* } & \multicolumn{16}{|c|}{ Reference strains $\dagger$} \\
\hline & 1 & 2 & 3 & 4 & 5 & 6 & 7 & $\mathbf{A}$ & B & $\mathbf{C}$ & D & $\mathbf{E}$ & $\mathbf{F}$ & $\mathbf{G}$ & $\mathbf{H}$ & $\mathbf{I}$ & $\mathbf{J}$ & $\mathbf{K}$ & $\mathbf{L}$ & $\mathbf{M}$ & $\mathbf{N}$ & $\mathbf{O}$ & $\mathbf{P}$ \\
\hline Pectin hydrolysis & + & + & + & $\mathrm{w}$ & - & - & - & + & + & + & - & - & - & - & - & - & - & - & - & - & - & - & - \\
\hline Growth at $36^{\circ} \mathrm{C}$ & + & + & 66 & + & 75 & + & - & + & + & - & - & + & + & + & - & + & + & - & - & + & - & - & - \\
\hline Growth at $39^{\circ} \mathrm{C}$ & 80 & 33 & - & + & - & 33 & - & + & - & - & - & + & + & + & - & + & - & - & - & - & - & - & - \\
\hline $\begin{array}{l}\text { Growth on Simmons' } \\
\text { citrate }\end{array}$ & 80 & + & 66 & - & 25 & - & 50 & + & - & + & - & - & + & + & - & - & - & - & - & - & - & - & - \\
\hline Growth in $5 \% \mathrm{NaCl}$ & 80 & 33 & + & + & 25 & 33 & + & - & + & + & + & + & + & + & + & + & + & + & - & + & + & + & - \\
\hline Gelatin hydrolysis & + & 66 & 66 & 40 & - & + & - & + & - & + & + & - & - & - & + & - & - & - & - & - & + & - & - \\
\hline Lecithin hydrolysis & + & + & - & - & - & - & - & + & - & - & - & - & - & - & - & - & - & - & - & - & - & - & - \\
\hline Production of indole & + & + & - & - & - & + & - & + & - & - & - & - & - & - & - & - & - & - & - & - & - & - & - \\
\hline Utilization of malonate & + & + & - & - & + & - & + & + & - & - & - & + & + & + & - & - & - & - & - & - & - & - & - \\
\hline \multicolumn{24}{|l|}{ Acid production from: } \\
\hline Arabinose & 40 & 33 & 33 & + & + & + & + & - & - & - & + & - & + & + & + & - & + & + & - & + & - & - & - \\
\hline Lactose & 60 & - & + & - & + & + & + & - & - & - & - & + & + & - & - & - & - & - & - & + & - & - & - \\
\hline Melibiose & + & - & + & - & + & + & + & + & - & - & - & - & - & + & - & + & - & - & + & + & + & - & - \\
\hline Raffinose & + & - & + & - & - & + & + & - & - & - & - & + & - & - & - & + & - & - & + & + & - & - & - \\
\hline \multicolumn{24}{|l|}{ Assimilation of: } \\
\hline D-Alanine & - & - & - & - & + & + & + & - & - & - & - & - & + & + & + & - & - & - & - & - & - & - & - \\
\hline L-Alanine & 60 & - & - & - & - & - & - & + & - & - & - & - & + & + & + & - & - & - & - & - & - & - & - \\
\hline L- $(+)$-Arabinose & + & + & + & + & + & + & + & + & + & + & + & - & + & + & + & - & + & + & - & + & - & - & - \\
\hline D- $(+)$-Cellobiose & 60 & 66 & + & + & 50 & + & + & - & - & + & - & - & + & + & - & - & - & - & - & - & - & - & - \\
\hline cis-Aconitate & 60 & - & - & - & 75 & + & + & - & - & - & - & - & + & + & + & - & - & - & - & - & - & - & + \\
\hline Aesculin & + & + & + & + & + & 66 & + & + & + & + & + & + & + & + & + & + & - & + & + & - & - & - & - \\
\hline D-Galacturonate & + & + & + & + & + & + & + & + & - & + & + & + & + & + & - & - & - & - & - & - & - & - & - \\
\hline$\beta$-Gentobiose & - & 33 & + & - & 25 & + & + & + & + & + & - & + & + & + & + & - & + & - & - & - & + & - & - \\
\hline D-Glucosamine & + & + & + & + & + & + & + & + & + & + & + & + & - & - & + & + & + & + & + & + & - & - & - \\
\hline D-Glucuronate & 80 & + & 66 & 40 & + & + & 50 & + & - & + & - & - & - & - & + & + & + & + & + & + & - & - & - \\
\hline L-Glutamate & + & 66 & 66 & 20 & + & + & + & + & + & - & + & + & + & + & + & + & + & - & - & + & - & - & - \\
\hline DL-Glycerate & 80 & 33 & + & + & 50 & 66 & 50 & + & - & + & - & - & - & + & - & + & - & - & + & - & - & - & - \\
\hline L-Histidine & - & - & - & - & + & + & + & - & - & - & - & - & - & - & + & - & - & - & - & - & - & - & - \\
\hline 5-Keto-D-gluconate & - & 33 & - & - & 25 & + & + & + & - & - & - & - & - & + & + & - & - & - & - & - & - & - & - \\
\hline 2-Keto-D-gluconate & 20 & 33 & - & - & + & + & + & - & + & - & - & - & + & + & + & - & - & - & - & - & - & - & - \\
\hline 2-Ketoglutarate & 20 & 66 & - & 40 & 25 & 33 & - & - & - & - & - & - & - & - & - & - & - & - & - & - & - & - & - \\
\hline DL-Lactate & 80 & + & - & + & + & + & + & + & + & + & - & - & + & + & + & - & - & - & - & - & - & - & - \\
\hline D-Lyxose & - & - & - & - & + & + & 50 & - & - & - & - & - & - & - & - & - & - & - & - & - & - & - & - \\
\hline D-Malate & + & + & - & - & + & 66 & - & + & - & - & - & - & - & - & - & - & - & - & - & - & - & - & - \\
\hline Maltose & - & - & - & - & + & + & + & - & - & - & - & - & + & + & + & - & - & + & - & - & - & - & - \\
\hline Maltotriose & - & - & - & - & + & + & + & - & - & - & - & - & + & + & + & - & - & - & - & - & - & - & - \\
\hline meso-Tartrate & + & + & - & - & + & 66 & - & + & - & + & - & - & - & - & - & - & - & - & - & - & - & - & - \\
\hline 1-O-Methyl $\alpha$-galactoside & 60 & 33 & + & - & - & + & + & + & - & - & - & - & - & - & + & - & - & - & - & + & - & - & - \\
\hline 1- $O$-Methyl $\beta$-galactoside & + & 66 & + & - & 75 & + & + & + & - & - & - & - & + & - & - & - & - & - & - & + & - & - & - \\
\hline Mucate & + & + & + & + & + & + & - & + & + & + & + & - & + & - & - & - & - & - & - & - & - & - & - \\
\hline myo-Inositol & + & + & + & + & + & + & + & - & + & + & + & - & - & - & + & - & - & - & + & - & + & - & + \\
\hline L-Proline & - & - & - & - & + & + & + & - & - & - & - & - & - & + & + & - & - & - & - & - & - & - & - \\
\hline Procatechuate & - & - & - & - & - & + & - & - & - & - & - & - & - & + & + & - & - & - & - & - & - & - & - \\
\hline Quinate & - & - & - & - & 25 & + & - & - & - & - & - & - & - & + & + & - & - & - & - & - & - & - & - \\
\hline$\alpha$-L-Rhamnose & 40 & + & + & + & + & 33 & + & + & + & + & + & + & + & + & - & - & - & - & - & - & - & - & - \\
\hline D-Saccharate & + & + & + & + & + & + & - & + & + & - & - & - & + & + & - & - & - & - & - & - & - & - & - \\
\hline Serine & + & + & + & 60 & + & + & + & + & - & - & + & - & + & + & + & - & - & - & - & - & - & - & - \\
\hline Trehalose & - & - & + & + & + & + & + & - & + & + & + & + & + & + & + & + & + & + & - & + & + & + & - \\
\hline trans-Aconitate & 40 & - & - & - & 25 & + & 50 & - & - & - & - & - & + & + & + & - & - & - & - & - & - & - & - \\
\hline
\end{tabular}


Samsonia erythrinae gen. nov., sp. nov.

Table 1 (cont.)

\begin{tabular}{|c|c|c|c|c|c|c|c|c|c|c|c|c|c|c|c|c|c|c|c|c|c|c|c|}
\hline \multirow[t]{2}{*}{ Characteristic } & \multicolumn{7}{|c|}{ Phenon no.* } & \multicolumn{16}{|c|}{ Reference strains $\dagger$} \\
\hline & 1 & 2 & 3 & 4 & 5 & 6 & 7 & $\mathbf{A}$ & B & $\mathrm{C}$ & D & $\mathbf{E}$ & $\mathbf{F}$ & $\mathbf{G}$ & $\mathbf{H}$ & $\mathbf{I}$ & $\mathbf{J}$ & $\mathbf{K}$ & $\mathbf{L}$ & $\mathbf{M}$ & $\mathbf{N}$ & $\mathbf{O}$ & $\mathbf{P}$ \\
\hline Trigonelline & - & - & - & + & 75 & + & 50 & - & - & - & - & - & + & + & + & - & - & - & - & - & - & - & - \\
\hline D-Xylose & + & + & + & - & + & + & - & + & + & + & - & - & + & - & - & - & - & + & - & + & - & + & - \\
\hline
\end{tabular}

* Reference strains in each phenon: 1, Pectobacterium chrysanthemi bvs 1, 3, 5, 6 and 8; 2, Pectobacterium chrysanthemi bvs 2,7 and 9; 3, Pectobacterium carotovorum subspp. carotovorum, atrosepticum and odoriferum; 5, Pantoea agglomerans, Pantoea agglomerans pv. milletiae, Pectobacterium cypripedii, Erwinia herbicola pv. gypsophilae; 6, Pantoea ananatis pvs ananatis and uredovora, Pantoea stewartii subsp. indologenes; 7, Erwinia percisina and Erwinia rhapontici. Phenon 4 contains Samsonia erythrinae strains CFBP 5236 ${ }^{\mathrm{T}}$, $5237,5238,5239$ and 5240.

$\uparrow$ Reference strains: A, Pectobacterium chrysanthemi bv. 4; B, Pectobacterium carotovorum subsp. betavasculorum; C, Pectobacterium carotovorum subsp. wasabiae; D, Erwinia psidii; E, Pectobacterium cacticida; F, Enterobacter cancerogenus; G, Enterobacter pyrinus; $\mathrm{H}$, Brenneria nigrifluens; I, Brenneria quercina; J, Brenneria rubrifaciens; K, Brenneria alni; L, Brenneria salicis; M, Pantoea stewartii subsp. stewartii; N, Erwinia amylovora; O, Erwinia mallotivora; P, Erwinia tracheiphila.

and reference stains of plant-pathogenic enterobacterial species is presented in this study. A dendrogram of phenotypic distances among the 41 strains is shown in Fig. 1. At a distance level of 0.28, 7 clusters and 16 strains with a separate position were observed. Phenotypic characteristics that differentiate the strains clustered in the different phenons and the unclustered strains of phytopathogenic Enterobacteriaceae are shown in Table 1.

Reference strains of Pectobacterium chrysanthemi biovars and type strains of Pectobacterium carotovorum subspecies were clustered in phenon 1 and 2 , and phenon 3, respectively, except Pectobacterium chrysanthemi bv. 4 and Pectobacterium carotovorum subsp. betavasculorum and subsp. wasabiae, which were unclustered (Fig. 1). As indicated in Table 2, the two species Pectobacterium chrysanthemi and Pectobacterium carotovorum are clearly distinguished by hydrolysis of lecithin, production of indole, utilization of malonate and assimilation of trehalose, as previously reported (Dickey \& Kelman, 1988; Bradbury, 1986; Leliott \& Dickey, 1984; Gallois et al., 1992). The characteristics that discriminate the nine Pectobacterium chrysanthemi biovars and the five Pectobacterium carotovorum subspecies are also indicated in Table 2.

Pectobacterium chrysanthemi (ex. Erwinia chrysanthemi) has been subdivided into biovars using 10 biochemical and physiological tests (Samson et al., 1987; Ngwira \& Samson, 1990). Five of these tests (growth at $39^{\circ} \mathrm{C}$, acid production from $\mathrm{D}$-arabinose, melibiose and raffinose, and assimilation of 5-keto-Dgluconate) were confirmed to be pertinent for distinguishing reference strains of Pectobacterium chrysanthemi biovars (Table 2). However, numerous additional characteristics that differentiate Pectobacterium chrysanthemi biovars were revealed by this study (Table 2). The five Pectobacterium carotovorum subspecies can be distinguished by the ability to grow at $36^{\circ} \mathrm{C}$ and in the presence of $5 \% \mathrm{NaCl}$, utilization of citrate (Simmons' medium), hydrolysis of gelatin, production of reducing compounds from sucrose, acid production from melibiose and $\alpha$-methyl glucoside, and assimilation of D-cellobiose and D-galacturonate (Table 2), as previously reported (Dickey \& Kelman, 1988; Bradbury, 1986; Leliott \& Dickey, 1984; Gallois et al., 1992; Goto \& Matsumoto, 1987). As shown in Table 2, additional tests can be used to discriminate the type strains of these subspecies.

The five strains CFBP $5236^{\mathrm{T}}$, CFBP 5237, CFBP 5238, CFBP 5239 and CFBP 5240 isolated from erythrina trees were clustered in a single phenon (phenon 4). These strains were weakly pectolytic (Sutton's medium) and were phenotypically related to Pectobacterium species (Fig. 1). However, they could be clearly distinguished from Pectobacterium carotovorum subspecies and Pectobacterium chrysanthemi biovars by numerous characteristics (Table 1).

Reference strains of Erwinia herbicola, Pantoea ananatis and Pantoea stewartii subsp. indologenes were clustered in two closely related phenons, 5 and 6 (Fig. $1)$; this is in accordance with the close relatedness or the synonymy of these taxa (Mergaert et al., 1984; Verdonck et al., 1987; Beji et al., 1988). The Pectobacterium cypripedii type strain was also included in phenon 5. Although belonging to the genus Pectobacterium (Hauben et al., 1998), Pectobacterium cypripedii is phenotypically more related to Pantoea species than to other Pectobacterium species, as previously observed (Mergaert et al., 1984; Verdonck et al., 1987). However, Pectobacterium cypripedii can be distinguished from the reference strains of Pantoea species and Erwinia herbicola included in phenon 5 by the assimilation of 5-keto-D-gluconate and quinate (positive for Pectobacterium cypripedii), and 1-Omethyl $\beta$-galactopyrannoside and trans-aconitate (negative for Pectobacterium cypripedii) (data not shown). Type strains of Pantoea ananatis pv. ananatis and pv. uredovora can be differentiated by aesculin hydrolysis, assimilation of DL-glycerate and growth in 
Table 2. Biochemical characteristics that differentiate reference strains of Pectobacterium chrysanthemi bvs 1-9 and type strains of Pectobacterium carotovorum subspecies

The characteristics that differentiate Pectobacterium chrysanthemi biovars are in bold face. The characteristics that differentiate Pectobacterium carotovorum subspecies are underlined.

\begin{tabular}{|c|c|c|c|c|c|c|c|c|c|c|c|c|c|c|}
\hline \multirow[t]{2}{*}{ Characteristic } & \multicolumn{9}{|c|}{ Pectobacterium chrysanthemi biovars } & \multicolumn{5}{|c|}{ Pectobacterium carotovorum subspecies* } \\
\hline & 1 & 2 & 3 & 4 & 5 & 6 & 7 & 8 & 9 & caro. & atro. & odori. & beta. & wasa. \\
\hline ADH (Moeller) & + & - & + & - & + & - & + & - & - & - & - & - & - & - \\
\hline Growth at $39^{\circ} \mathrm{C}$ & - & + & + & + & + & + & - & + & - & - & - & - & - & - \\
\hline Growth at $36^{\circ} \mathrm{C}$ & + & + & + & + & + & + & + & + & + & + & - & + & + & - \\
\hline Growth on Simmons' citrate & - & + & + & + & + & + & + & + & + & - & + & + & - & + \\
\hline Growth in $5 \% \mathrm{NaCl}$ & + & + & + & - & + & - & - & + & - & + & + & + & + & + \\
\hline$\overline{\text { Gelatin hydrolysis }}$ & + & - & + & - & + & + & + & + & + & + & - & + & - & + \\
\hline Lecithin hydrolysis & + & + & + & + & + & + & + & + & + & - & - & - & - & - \\
\hline Reducing substances from sucrose & - & - & - & - & - & - & - & - & - & - & + & + & + & - \\
\hline Production of indole & + & + & + & + & + & + & + & + & + & - & - & - & - & - \\
\hline Utilization of malonate & + & + & + & + & + & + & + & + & + & - & - & - & - & - \\
\hline Utilization of inulin & + & - & - & - & + & - & + & - & + & - & - & - & + & - \\
\hline \multicolumn{15}{|l|}{ Acid production from: } \\
\hline D-Arabinose & - & + & + & + & - & - & - & + & - & - & - & + & - & - \\
\hline Lactose & - & - & + & - & + & - & - & + & - & + & + & + & - & - \\
\hline Melibiose & + & - & + & + & + & + & - & + & - & + & + & + & + & - \\
\hline$\underline{\alpha \text {-Methyl glucoside }}$ & - & - & - & - & - & - & + & - & - & - & + & + & + & - \\
\hline Raffinose & + & - & + & + & + & + & - & + & - & + & + & + & + & - \\
\hline \multicolumn{15}{|l|}{ Assimilation of: } \\
\hline L-Alanine & - & - & + & + & + & + & - & - & - & - & - & - & - & - \\
\hline D- $(+)$-Cellobiose & - & + & + & - & + & - & + & - & - & - & + & + & + & + \\
\hline cis-Aconitate & - & - & + & - & + & - & - & + & - & - & - & - & - & - \\
\hline trans-Aconitate & - & - & + & - & - & - & - & + & - & - & - & - & - & - \\
\hline D-Galacturonate & + & + & + & + & + & + & + & + & + & + & + & + & - & + \\
\hline$\overline{\beta \text {-Gentobiose }}$ & - & + & - & + & - & - & - & - & - & + & + & + & + & + \\
\hline D-Glucuronate & + & + & + & + & + & - & + & + & + & + & + & - & - & + \\
\hline$\overline{\text { L-Glutamate }}$ & + & + & + & + & + & + & + & + & - & + & - & + & + & - \\
\hline DL-Glycerate & + & - & + & + & + & - & + & + & - & + & + & + & - & + \\
\hline 5-Keto-D-gluconate & - & + & - & + & - & - & - & - & - & - & - & - & - & - \\
\hline 2-Keto-D-gluconate & - & + & + & - & - & - & - & - & - & - & - & - & + & - \\
\hline 2-Ketoglutarate & - & + & - & - & + & - & + & - & - & - & - & - & - & - \\
\hline DL-Lactate & + & + & + & + & + & - & + & + & + & - & - & - & + & + \\
\hline Lactulose & - & - & - & - & - & - & - & - & - & + & + & + & - & - \\
\hline D-Malate & + & + & + & + & - & + & + & + & + & - & - & - & - & + \\
\hline meso-Tartrate & + & + & + & + & - & + & + & + & + & - & - & - & - & + \\
\hline 1-O-Methyl $\alpha$-galactopyrannoside & + & - & - & + & + & + & + & - & - & + & + & + & - & - \\
\hline 1-O-Methyl $\beta$-galactopyrannoside & + & + & + & + & + & + & + & + & - & - & + & + & + & - \\
\hline Palatinose & - & - & - & - & - & - & - & - & - & - & + & + & + & - \\
\hline$\alpha$-L-Rhamnose & + & + & + & + & + & - & + & - & + & + & + & + & + & + \\
\hline L- $(+)$-Tartrate & - & + & + & + & - & - & - & + & - & - & - & - & - & - \\
\hline D- $(-)$-Tartrate & + & + & - & + & - & - & + & - & + & - & - & - & - & - \\
\hline Trehalose & - & - & - & - & - & - & - & - & - & + & + & + & + & + \\
\hline
\end{tabular}

* caro., carotovorum; atro., atrosepticum; odori., odoriferum; beta., betavasculorum; wasa., wasabiae.

$5 \% \mathrm{NaCl}$ (positive for Pantoea ananatis pv. ananatis), and acid production from raffinose and assimilation of meso-tartrate and $\mathrm{D}(+)$-malate (positive for Pantoea ananatis pv. uredovora) (data not shown). Erwinia percisina and Erwinia rhapontici type strains clustered in phenon 7 at a high distance level $(0 \cdot 26)$ and can be differentiated by numerous characteristics: assimilation of adonitol, erythritol, D-glucuronate, lactulose, D-sorbitol, D-tartrate, trans-aconitate (positive for Erwinia persicina), and growth on Simmons' citrate medium and assimilation of dulcitol, DLglycerate, D-lyxose, maltitol, $\mathrm{D}(+)$-melezitose, 1-O- 


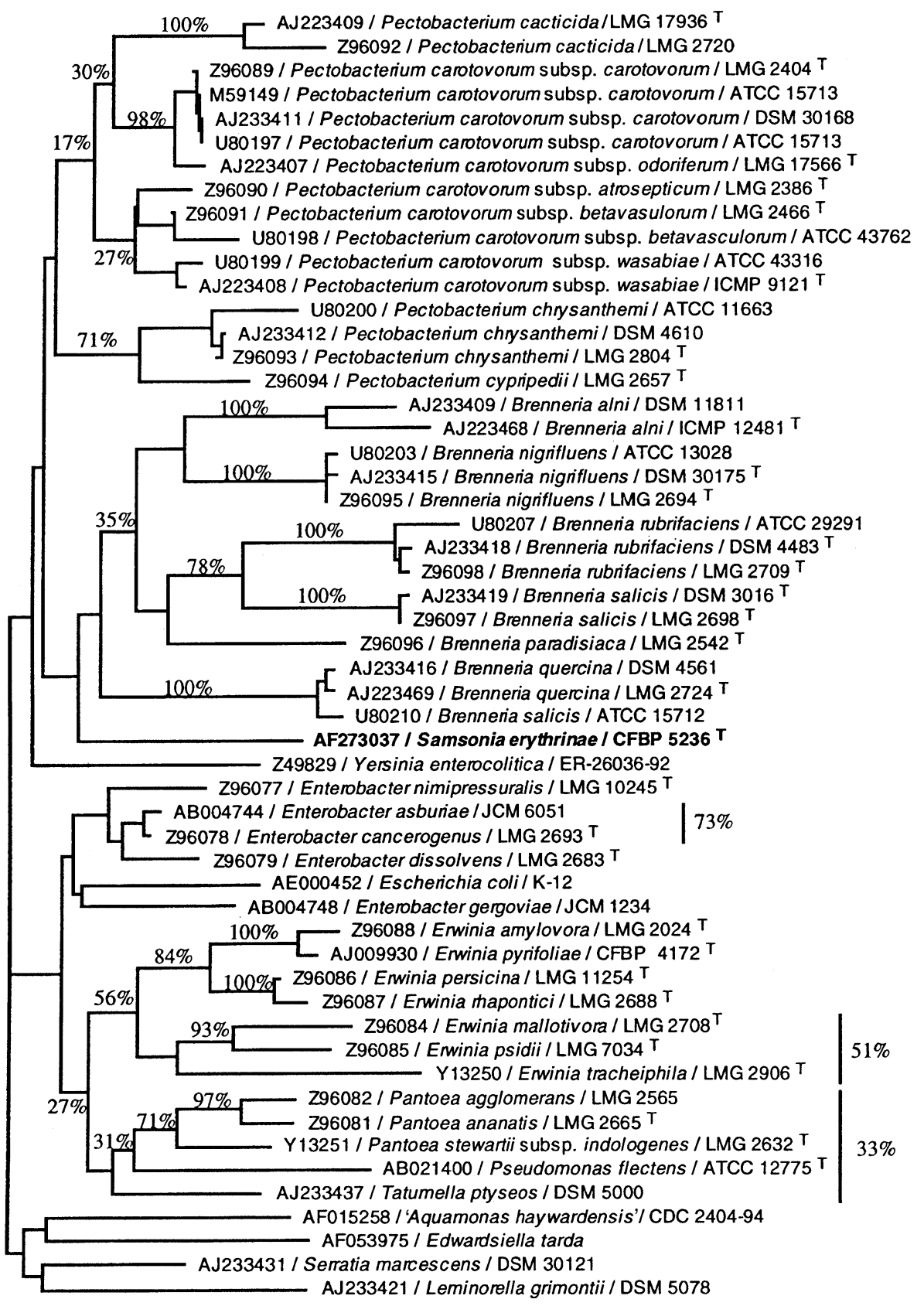

Fig. 2. For legend see page 1299.

methyl $\alpha$-D-glucoside, palatinose, D-turanose, xylitol (positive for Erwinia rhapontici) (data not shown). Erwinia species which have been recently transferred to the new genus Brenneria as $B$. nigrifluens, $B$. quercina, B. rubrifaciens, $B$. alni and $B$. salicis were related to the other strains included in this study at a high level of phenotypic distance $(>0.5)$, together with Erwinia amylovora, Erwinia mallotivora and Erwinia tracheiphila, and Pantoea stewartii subsp. stewartii (Fig. 1). All these strains could be clearly distinguished by numerous phenotypic characteristics (Table 1).

Numerical analysis of phenotypic data from Erwinia species has been previously reported (Mergaert et al., 1984; Verdonck et al., 1987). Mergaert et al. (1984) studied 123 Erwinia strains using commercially available biochemical strips API20E and API50CH (acid production of 49 organic substrates) and 9 API enzyme systems, whereas Verdonck et al. (1987) analysed the 
(b)

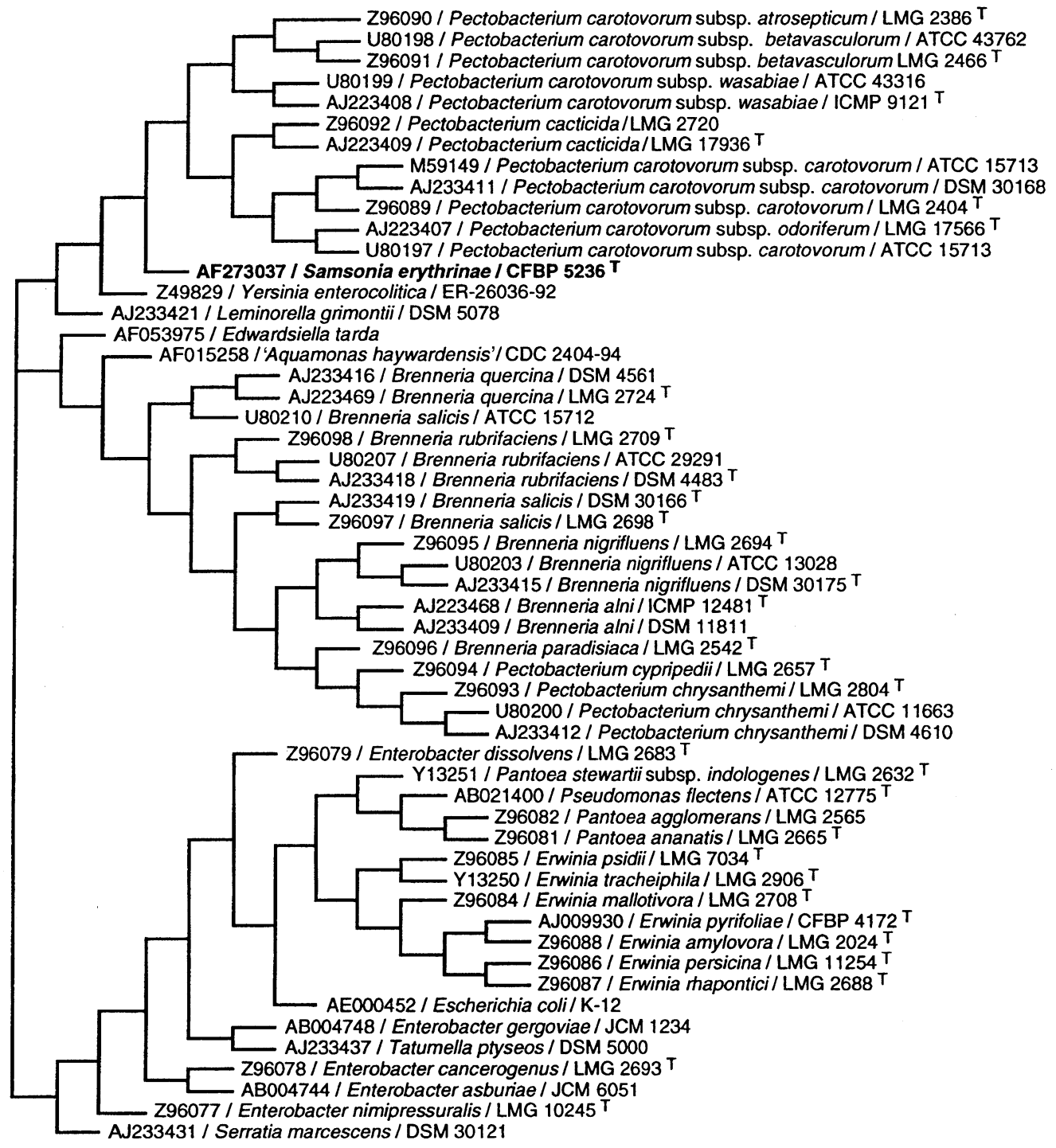

Fig. 2. For legend see page 1299.

phenotypic features obtained with API20E and API50CH strips of 529 strains, including 421 strains of Erwinia species. These studies, which were performed on large collections of strains belonging to the species described at that time, remain relevant and significant. However, the taxonomy of plant-pathogenic Enterobacteriaceae has been substantially modified and improved during the last two decades, so that new phenotypic data were needed. The phenotypic analysis presented here included type and reference strains of the plant-pathogenic Enterobacteriaceae known at present, and gives additional and updated information on the phenotypic features of these bacteria. The 22 conventional tests and the commercial Biotype 100 strips based on the assimilation of 99 organic substrates that we used here allow the clear discrimination of the type and reference strains of species, subspecies, pathovars and biovars of plant-pathogenic Enterobacteriaceae, and thus could be useful for their identification.

Moreover, our phenotypic data showed that strains isolated from diseased erythrina trees formed a homogeneous phenon different from other plant-pathogenic Enterobacteriaceae, as suggested by a previous preliminary study (Sutra et al., 1999).

\section{Phylogenetic analyses of 16S rDNA sequences}

An estimated $97.5 \%$ of the primary sequence of the 16S rDNA gene was determined for strain CFBP $5236^{\mathrm{T}}$, corresponding to 1503 bases from positions 6 to 1507 according to the numbering of the E. coli $16 \mathrm{~S}$ rRNA gene sequence (Brosius et al., 1981). The 16S 


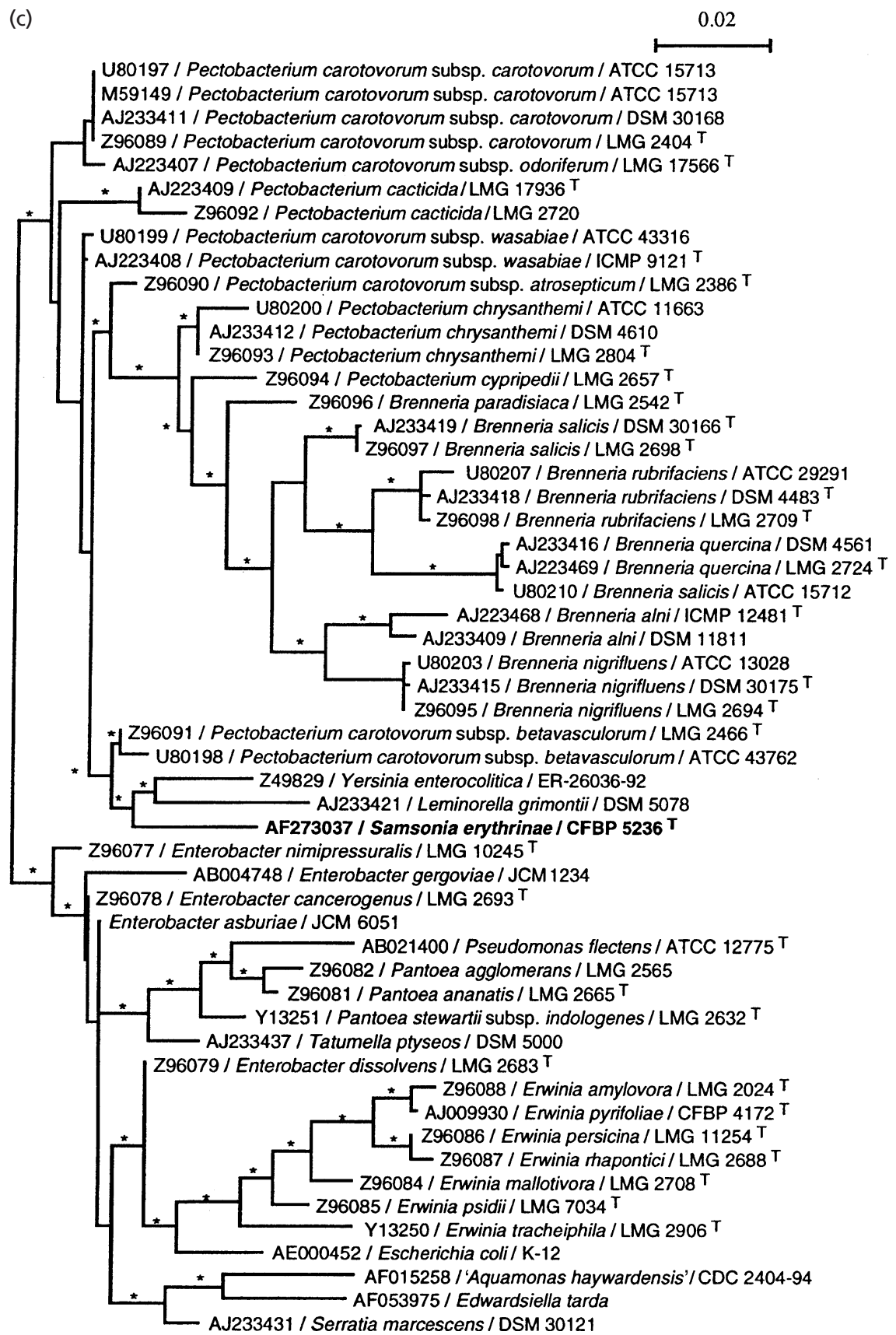

Fig. 2. Phylogenetic analyses of the $16 \mathrm{~S}$ rDNA sequence of strain CFBP $5236^{\top}$ and reference strains of plant-pathogenic Enterobacteriaceae. Three methods were used to analyse the phylogenetic position of strain CFBP $5236^{\top}$, as detailed in Methods: (a) a neighbour-joining algorithm, including bootstrap values as indicated along branches; (b) a maximumparsimony method; (c) a maximum-likelihood method (branches with an asterisk were positive at $P<0.01$ ).

rDNA sequence of strain CFBP $5236^{\mathrm{T}}$ had $93 \cdot 8-94 \cdot 7 \%$ similarity with the 16S rDNA of Erwinia species, 94.3-96.0 \% similarity with the $16 \mathrm{~S}$ rDNA of Brenneria species, $92 \cdot 7-96 \cdot 5 \%$ similarity with the $16 \mathrm{~S}$ rDNA of Pectobacterium species or subspecies, and 93.3-93.7\% similarity with the $16 \mathrm{~S}$ rDNA of Pantoea species (positions 28-1469). In the description of the genera Erwinia, Pectobacterium and Brenneria, Hauben et al. (1998) have proposed nucleotide signature positions of the $16 \mathrm{~S}$ rDNA that allow the differentiation of these three genera from each other. Discrepancies were found between the nucleotide signatures reported by these authors and those deduced from our own sequence comparison: (i) positions 593, 594, 598 and 599 correspond to positions 594, 595, 599 and 600, respectively, in our alignment by reference to $E$. coli $16 \mathrm{~S}$ rDNA numbering; (ii) some positions that were considered characteristic (Hauben et al., 1998) are not: 
positions 593, 594 and 1219 (594, 595 and 1219 according to our alignment), which correspond respectively to $\mathrm{T}$ or $\mathrm{C} / \mathrm{T}, \mathrm{A}$ and $\mathrm{A}$ for all three genera. These three positions being excluded, the 16S rDNA sequence of strain CFBP $5236^{\mathrm{T}}$ possessed 8 of the 10 signature nucleotides defined for the genus Brenneria, 10 of the 17 signature nucleotides defined for the genus Pectobacterium and 3 of the 14 signature nucleotides defined for the genus Erwinia (Hauben et al., 1998). The 16S rDNA sequence of strain CFBP $5236^{\mathrm{T}}$ can be differentiated from the sequences of Brenneria species at positions 379 and 384 (C and $\mathrm{G}$ for strain CFBP $5236^{\mathrm{T}}$ instead of $\mathrm{G}$ and $\mathrm{C}$ for Brenneria species), from the sequences of Pectobacterium species at positions 599, 600, 638, 639, 646, 839 and 847 (respectively C, A, T, G, G, G and C for strain CFBP $5236^{\mathrm{T}}$ instead of T, G, C, A, A, C and G for Pectobacterium species) and from the sequences of Erwinia species at positions 408, 839, 847, 987, 988, 989, 1216, 1217, 1218, 1308 and 1329 (respectively G, G, C, A, C, T, A, G, T, T and A for strain CFBP $5236^{\mathrm{T}}$ instead of A, C, G, G, G, C, G, C, C, C and G for Erwinia species) (Hauben et al., 1998). Nucleotide signatures that are specific, i.e. not shared by the other genera, were found for Brenneria species and Erwinia species: G, A, C and G at positions 379, 381, 384 and 839, respectively, for Brenneria species (C, C, G and C for Erwinia and Pectobacterium species) as reported by Hauben et al. (1998), and G, C, G, C and $\mathrm{C}$ at positions 988, 989, 1216, 1217 and 1218, respectively, for Erwinia species (C, T, A, G/A or G, and $\mathrm{T}$ for Brenneria and Pectobacterium species). Only one specific nucleotide signature was found for strain CFBP 5336, A at position 1047. No specific signature was found for Pectobacterium species.

All three methods of sequence analysis (bioNJ, maximum-likelihood and maximum-parsimony) showed that strain CFBP $5236^{\mathrm{T}}$ always clustered within the $\gamma-03$ division of the Proteobacteria, with species of the genera Pectobacterium, Brenneria and Erwinia (data not shown). More detailed analyses were then conducted based on 16S rDNA sequences of strains including type strains of species of these three genera as well as representatives of outgroups selected within the Enterobacteriaceae (Fig. 2). Results of bioNJ analysis showed that Pectobacterium and Brenneria species and subspecies formed two different clusters, with strain CFBP $5236^{\mathrm{T}}$ being included in the Brenneria cluster (Fig. 2a). However, bootstrap analyses based on 500 samplings showed no support for the genus Pectobacterium and low support (35\%) for the genus Brenneria. Analyses of 16S rDNA sequences by both maximum-parsimony (Fig. 2b) and maximumlikelihood (Fig. 2c) showed that Brenneria and Pectobacterium species consisted of intermixed clusters. Strain CFBP $5236^{\mathrm{T}}$ was grouped with subsets of Pectobacterium species according to maximum-parsimony (Fig. 2b) and with Yersinia enterocolitica and Leminorella grimontii according to maximum-likelihood (Fig. 2c). Whatever the method of analysis used, Erwinia species formed a unique cluster (Fig. 2a-c).
Two phylogenetic analyses of Erwinia species based on 16S rDNA sequences have been recently reported (Kwon et al., 1997; Hauben et al., 1998). The study of Kwon et al. (1997) showed that the genus Erwinia was phylogenetically heterogeneous and that Erwinia species were distributed into four different clusters (I-IV) that were intermixed with members of other genera of the family Enterobacteriaceae. Using a similar but enlarged approach, Hauben et al. (1998) analysed the $16 \mathrm{~S}$ rDNA sequences of the type strains of all phytopathogenic Enterobacteriaceae. They also obtained four clusters, confirming the heterogeneity of the genus Erwinia. Cluster I represents the so-called 'true' erwinias and contained Erwinia amylovora, Erwinia mallotivora, Erwinia persicina, Erwinia psidii, Erwinia rhapontici and Erwinia tracheiphila. Pectolytic Erwinia species (Erwinia carotovora and Erwinia chrysanthemi) and Erwinia cypripedii included in cluster II were united in the genus Pectobacterium as Pectobacterium carotovorum, Pectobacterium chrysanthemi and Pectobacterium cypripedii, respectively. Erwinia species of cluster III were classified in the new genus Brenneria as $B$. alni, $B$. nigrifluens, $B$. paradisiaca, B. quercina, B. rubrifaciens and B. salicis, whereas cluster IV contained plant-pathogenic Pantoea species. Moreover, Hauben et al. (1998) defined nucleotide signature positions of the $16 \mathrm{~S}$ rDNA that differentiate the four genera Erwinia, Brenneria, Pectobacterium and Pantoea. Although the number of sequences analysed was different, results obtained in these two studies were in agreement since clusters I, II, III and IV defined by Hauben et al. (1998) corresponded to clusters II, III, IV and I obtained by Kwon et al. (1997), respectively. However, it must be pointed out that in both studies, the only method used for analysing $16 \mathrm{~S}$ rDNA sequences was the neighbourjoining method and that the clusters obtained were supported by low bootstrap values. The basis of modern bacterial taxonomy relies mostly on a cladistic model: bacterial species grouped within a single genus descend from a common ancestor from which no other species that is not within the genus also descends. Although gene trees cannot always be equated to species trees (Slowinski \& Page, 1999), gene trees derived from 16S rDNA sequences have so far been considered as good indicators of species trees and used accordingly in bacterial systematics. An important rule for analysing gene trees is to estimate the robustness of a topology, but also to ascertain whether the tree obtained is the 'true' tree. The consistency of any given method is only valid within limits (Felsenstein, 1998; Huelsenbeck \& Hillis, 1993). A given method may produce a robust tree, attested by high bootstrap values, that is not the true tree. One way to circumvent this problem is to compare different methods that rely on different models (Kim, 1993). The basis of this approach is that it is unlikely that different methods, if they all produce an incorrect tree, will produce the same tree. In conclusion, if all methods indicate the same topology, there is a good chance that the true tree has been obtained; in contrast, when 
different trees are obtained, the true tree cannot be inferred from the data.

In this paper, results of $16 \mathrm{~S}$ rDNA sequence analysis by neighbour-joining (bioNJ) showed that the genera Pectobacterium, Brenneria and Erwinia formed three separate clusters and were in full agreement with previous publications that used only this method of analysis (Kwon et al., 1997; Hauben et al., 1998). However, the tree obtained by neighbour-joining was in contradiction to the trees obtained by maximumparsimony and maximum-likelihood, in which Pectobacterium and Brenneria species are distributed in several intermixed clusters, indicating that the genera Pectobacterium and Brenneria cannot be described as clades on the basis of $16 \mathrm{~S}$ rDNA sequence analysis only. These data are in agreement with recent results obtained by Spröer et al. (1999) who showed that Pectobacterium and Brenneria genera were not clearly phylogenetically separated on the basis of $16 \mathrm{~S}$ rDNA sequence analyses using three different treeing algorithms. Results presented in this study could be used as a basis for separating the different species (now grouped in only the two genera Pectobacterium and Brenneria) into several new genera, each of which supported by all methods at the phylogenetic level. This is probably not the proper approach, because the smallest clades common to the three methods may not reflect the true existence of a larger genus (if, for example, only the neighbour-joining tree is incorrect). Consequently, it is now necessary to examine all phenotypic and molecular data in a polyphasic approach, or perhaps to acquire more sequence data, to resolve this taxonomic problem.

The 16S rDNA sequence of strain CFBP $5236^{\mathrm{T}}$, which is representative of strains isolated from erythrina, did not contain all the nucleotide signatures defined for the genera Erwinia, Pectobacterium or Brenneria (Hauben et al., 1998). Moreover, the position of strain CFBP $5236^{\mathrm{T}}$ in the different trees (Fig. 2) was so variable that it cannot be attributed to any recognized genus, no matter what final decision is taken about the taxonomic status of the genera Pectobacterium and Brenneria.

\section{DNA-DNA hybridizations and DNA base composition}

The results of DNA-DNA hybridizations are shown in Table 3. The labelled DNAs from strains CFBP $5236^{\mathrm{T}}$ and CFBP 5237 exhibited high levels of reassociation (89-100\% hybridization) with DNAs from other strains isolated from erythrina. In contrast, low levels of reassociation were observed with DNAs from reference strains of phytopathogenic Enterobacteriaceae. The percentages of hybridization of DNAs from strains CFBP $5236^{\mathrm{T}}$ and CFBP 5237 ranged from 7 to $29 \%$, from 14 to $20 \%$, from 4 to $33 \%$, from 7 to $30 \%$ and from 5 to $11 \%$ with DNA from reference strains of Pectobacterium species, Brenneria species, Erwinia species, Pantoea species and Enterobacter species, respectively (Table 3). These results indicated that strains isolated from erythrina formed a homogeneous genomic group with a low level of DNA relatedness with all other plantpathogenic Enterobacteriaceae.

The DNA G + C content of both strains CFBP $5236^{\mathrm{T}}$ and CFBP 5237 was $57.0 \mathrm{~mol} \%$. This value is slightly more than the $\mathrm{G}+\mathrm{C}$ values previously reported for the genera Erwinia (49.8-54.1 mol\%), Brenneria (51.3$56 \cdot 1 \mathrm{~mol} \%$ ) and Pectobacterium (50.5-56.1 mol\%) (Leliott \& Dickey, 1984; Hauben et al., 1998).

On the basis of phenotypic data, 16S rDNA sequence analyses and results of DNA-DNA hybridizations, we conclude that strains isolated from diseased erythrina trees should be recognized as a new genus, Samsonia, and as a new species, Samsonia erythrinae gen. nov., sp. nov.

\section{Description of Samsonia gen. nov.}

Samsonia (Sam.so'ni.a. M.L. fem. n. Samsonia after the French phytobacteriologist Régine Samson, INRA, Angers, France, who works on pectolytic Erwinia).

The description below is based on data from this study and those obtained by Sutra et al. (1999). Cells are Gram-negative, oxidase-negative and catalase-positive. They are rod-shaped with rounded ends, and are motile by means of peritrichous flagella. The strains are $\beta$-galactosidase-positive, produce acetoin but not hydrogen sulfide, and do not possess arginine dihydrolase, lysine decarboxyase, ornithine decarboxylase, urease or tryptophan desaminase. Glucose is fermented without gas production. Nitrate is reduced. Strains hydrolyse aesculin but not gelatin, Tween 80, casein or lecithin. They do not utilize citrate and malonate as carbon source and do not produce indole from tryptophan. The type species is Samsonia erythrinae.

\section{Description of Samsonia erythrinae sp. nov.}

Samsonia erythrinae (e.ry.thri'nae. L. gen. n. erythrinae of Erythrina, referring to plants of the genus Erythrina, family Fabaceae, from which the organism was isolated).

The description of Samsonia erythrinae is the same as that of the genus. Colonies on YBGA medium are white to light beige, circular, convex and glistening, with regular edges and a diameter of 2-5 mm after $48 \mathrm{~h}$ at $28^{\circ} \mathrm{C}$. The organism grows at 28,36 and $39^{\circ} \mathrm{C}$. Strains produce acid from amygdaline, arabinose, inositol, mannitol, rhamnose and saccharose but not from D-(+)-arabitol, erythritol, inulin, lactose, melibiose, $\alpha$-methyl glucoside, raffinose and sorbitol. Acid production from mannitol is variable. They do not produce reducing compounds from sucrose. No hypersensitivity reaction is produced on tobacco leaves (Sutra et al., 1999). Samsonia erythrinae strains as- 
Table 3. Results of DNA-DNA hybridization experiments

\begin{tabular}{|c|c|c|}
\hline \multirow[t]{2}{*}{ Strain } & \multicolumn{2}{|c|}{$\begin{array}{l}\text { Percentage of reassociation with } \\
\text { labelled DNA from strains: }\end{array}$} \\
\hline & CFBP 5236 & CFBP 5237 \\
\hline \multicolumn{3}{|l|}{ Samsonia erythrinae } \\
\hline CFBP $5236^{\mathrm{T}}$ & 100 & 95 \\
\hline CFBP 5237 & 100 & 100 \\
\hline CFBP 5238 & 100 & 89 \\
\hline CFBP 5239 & 95 & ND \\
\hline CFBP 5240 & 93 & ND \\
\hline \multicolumn{3}{|l|}{ Pectobacterium carotovorum } \\
\hline subsp. carotovorum CFBP $2046^{\mathrm{T}}$ & 29 & ND \\
\hline subsp. atrosepticum CFBP $1526^{\mathrm{T}}$ & 25 & ND \\
\hline subsp. odoriferum CFBP $1878^{\mathrm{T}}$ & 10 & 5 \\
\hline subsp. betavasculorum CFBP $2122^{\mathrm{T}}$ & 27 & 28 \\
\hline subsp. wasabiae CFBP $3304^{\mathrm{T}}$ & 29 & ND \\
\hline \multicolumn{3}{|l|}{ Pectobacterium chrysanthemi } \\
\hline bv. 1 CFBP 1200 & 29 & ND \\
\hline bv. 2 CFBP 2051 & 12 & ND \\
\hline bv. 3 CFBP 1447 & 9 & ND \\
\hline bv. 4 CFBP 3477 & 16 & ND \\
\hline bv. 5 CFBP $2048^{\mathrm{T}}$ & 8 & ND \\
\hline bv. 6 CFBP 1270 & 16 & 12 \\
\hline bv. 7 CFBP 2015 & 21 & ND \\
\hline bv. 8 CFBP 2052 & 9 & ND \\
\hline bv. 9 CFBP 1805 & 10 & ND \\
\hline Pectobacterium cacticida $\mathrm{CFBP} 3628^{\mathrm{T}}$ & 20 & ND \\
\hline Pectobacterium cypripedii CFBP $3613^{\mathrm{T}}$ & 7 & ND \\
\hline Erwinia amylovora CFBP $1232^{\mathrm{T}}$ & 2 & 8 \\
\hline Erwinia percisina CFBP $3622^{\mathrm{T}}$ & 6 & ND \\
\hline Erwinia rhapontici CFBP $3618^{\mathrm{T}}$ & 5 & ND \\
\hline Erwinia mallotivora CFBP $2503^{\mathrm{T}}$ & ND & 4 \\
\hline Erwinia tracheiphila CFBP $2355^{\mathrm{T}}$ & ND & 33 \\
\hline Erwinia psidii CFBP $3627^{\mathrm{T}}$ & ND & 7 \\
\hline Brenneria nigrifluens CFBP $3616^{\mathrm{T}}$ & ND & 20 \\
\hline Brenneria rubrifaciens CFBP $3619^{\mathrm{T}}$ & ND & 19 \\
\hline Brenneria quercina CFBP $3617^{\mathrm{T}}$ & 8 & ND \\
\hline Brenneria alni CFBP $3923^{\mathrm{T}}$ & ND & 14 \\
\hline Brenneria salicis CFBP $802^{\mathrm{T}}$ & ND & 20 \\
\hline Erwinia herbicola pv. gypsophilae CFBP 11141 & 5 & ND \\
\hline Pantoea agglomerans CFBP 2240 & 5 & ND \\
\hline Pantoea agglomerans pv. milletiae CFBP 3615 & 8 & ND \\
\hline Pantoea ananatis pv. ananatis CFBP $3612^{\mathrm{T}}$ & 7 & 8 \\
\hline Pantoea ananatis pv. uredovora CFBP 3621 & 8 & ND \\
\hline Pantoea stewartii subsp. stewartii CFBP $3620^{\mathrm{T}}$ & 30 & ND \\
\hline Enterobacter cancerogenus CFBP $4167^{\mathrm{T}}$ & ND & 11 \\
\hline Enterobacter pyrinus CFBP $4168^{\mathrm{T}}$ & ND & 10 \\
\hline
\end{tabular}

ND, Not determined.

similate the following substrates (Biotype 100 strips): $\mathrm{N}$-acetylglucosamine, L- $(+)$-arabinose, L-aspartate, D$(+)$-cellobiose, $\mathrm{D}-(+)$-fructose, fumarate, $\mathrm{D}-(+)$-galactose, D-gluconate, D-glucosamine, D- $(+)$-glucose, glycerate, glycerol, 2-keto-D-gluconate, DL-lactate, L- (-)-malate, D-mannitol, mucate, myo-inositol, Lrhamnose, D-saccharate, succinate, sucrose, D- $(+)$ trehalose and trigonelline. They do not assimilate D-alanine, L-alanine, adonitol, 4-aminobutyrate, 5aminovalerate, D- $(+)$-arabitol, L-(-)-arabitol, ben- 
zoate, betaine, caprate, caprylate, cis-aconitate, citrate, $m$-coumarate, dulcitol, erythritol, ethanolamine, $\alpha$-L-fucose, gentisate, $\beta$-gentobiose, $\beta$-glucuronide, histamine, histidine, $m$ - and $p$-hydroxybenzoate, DL$\beta$-hydroxybutyrate, hydroxyquinoleine, itaconate, 5-keto-D-gluconate, lactose, lactulose, lyxose, D- $(+)-$ malate, malonate, maltitol, maltose, maltotriose, D$(+)$-melezitose, D- $(+)$-melibiose, meso-tartrate, 1-Omethyl $\alpha$-galactopyranoside, $1-O$-methyl $\beta$-galactopyranoside, 1-O-methyl $\alpha$-glucopyranoside, 1-Omethyl $\beta$-glucopyranoside, 3- $O$-methyl D-glucose, palatinose, phenylacetate, 3-phenylpropionate, Lproline, propionate, protocatechuate, putrescine, quinate, D- $(+)$-raffinose, D-sorbitol, L- $(+)$-sorbose, D-tagatose, D- $(-)$-tartrate, L- $(+)$-tartrate, transaconitate, tricarballylate, tryptamine, L-tryptophan, Ltyrosine, D- $(+)$-turanose, xylitol or D- $(+)$-xylose. The assimilation of D-galacturonate, D-glucuronate, Lglutamate, L-serine and 2-oxoglutarate is variable. DNA G + C content of strains CFBP $5236^{\mathrm{T}}$ and 5237 is $57.0 \mathrm{~mol} \%$. Strains of Samsonia erythrinae cause bark necrotic lesions on Erythrina sp. trees. The type strain is CFBP $5236^{\mathrm{T}}\left(=\right.$ ICMP $\left.13937^{\mathrm{T}}\right)$.

\section{ACKNOWLEDGEMENTS}

The authors are grateful to Solange Belouin, Karine Perlemoine and Alain Huard for technical assistance.

\section{REFERENCES}

Ayers, S. H., Rupp, P. \& Johnson, W. T. (1919). A Study of Alkaliforming Bacteria in Milk. Bulletin no. 782. Washington, DC: US Department of Agriculture.

Beji, A., Mergaert, J., Gavini, F., Izard, D., Kersters, K., Leclerc, H. \& De Ley, J. (1988). Subjective synonymy of Erwinia herbicola, Erwinia milletiae, and Enterobacter agglomerans and redefinition of the taxon by genotypic and phenotypic data. Int J Syst Bacteriol 38, 77-88.

Bonnet, P. (1973). Les Erwinia pectinolytiques. I. Diagnostic biochimique rapide. Ann Phytopathol 5, 355-376.

Bradbury, J. F. (1986). Guide to Plant Pathogenic Bacteria. Kew: CAB International Mycological Institute.

Brenner, D. J., McWorter, A. C., Leete Knutson, J. K. \& Steigerwalt, A. G. (1982). Escherichia vulneris: a new species of Enterobacteriaceae associated with human wounds. J Clin Microbiol 15, 1133-1140.

Brosius, J., Dull, T. J., Sleeter, D. D. \& Noller, H. F. (1981). Gene organization and primary structure of a ribosomal RNA operon from Escherichia coli. J Mol Biol 148, 107-127.

Croza, J. M., Brenner, D. J. \& Falkow, S. (1973). Use of a singlestranded specific nuclease for analysis of bacterial and plasmid deoxyribonucleic acid homo- and heteroduplexes. J Bacteriol 115, 904-911.

Descamps, P. \& Véron, M. (1981). Une méthode de choix des caractères d'identification basée sur le théorème de Bayes et la mesure de l'information. Ann Microbiol 132B, 157-170.

Dickey, R. S. \& Kelman, A. (1988). Erwinia "Carotovora" or soft rot group. In Laboratory Guide for Identification of Plant Pathogenic Bacteria, 2nd edn, pp. 44-46. Edited by N. W. Schaad. St Paul, MN: American Phytopathological Society.
Feinberg, A. P. \& Vogelstein, B. (1983). A technique for radiolabeling DNA restriction endonuclease fragments to high specific activity. Anal Biochem 132, 6.

Felsenstein, J. (1998). Phylogenies from molecular sequences: inference and reliability. Annu Rev Genet 22, 521-565.

Gallois, A., Samson, R., Ageron, E. \& Grimont, P. A. D. (1992). Erwinia carotovora subsp. odorifera subsp. nov., associated with odorous soft rot of chicory (Cichorium intybus L.). Int J Syst Bacteriol 42, 582-588.

Gascuel, O. (1997). BIONJ: an improved version of the NJ algorithm based on a simple model of sequence data. Mol Biol Evol 14, 685-695.

Goto, M. \& Matsumoto, K. (1987). Erwinia carotovora subsp. wasabiae subsp. nov. isolated from diseased rhizomes and fibrous roots of Japanese horseradish (Eutrema wasabi Maxim.). Int J Syst Bacteriol 37, 130-137.

Grimont, P. A. D., Popoff, M. Y., Grimont, F., Coynault, C. \& Lemelin, M. (1980). Reproducibility and correlation study of three deoxynucleic acid hybridization procedures. Curr Microbiol 4, 325-330.

Hauben, L., Moore, E. R. B., Vauterin, L., Steenackers, M., Mergaert, J., Verdonck, L. \& Swings, J. (1998). Phylogenetic position of phytopathogens within the Enterobacteriaceae. Syst Appl Microbiol 21, 384-397.

Huelsenbeck, J. P. \& Hillis, D. M. (1993). Success of phylogenetic methods in the four-taxon case. Syst Biol 42, 247-264.

Kim, J. (1993). Improving the accuracy of phylogenetic estimation by combining different methods. Syst Biol 42, 331-334.

Kwon, S.-W., Go, S.-J., Kang, H.-W., Ryu, J.-C. \& Jo, J.-K. (1997). Phylogenetic analysis of Erwinia species based on 16S rRNA gene sequences. Int J Syst Bacteriol 47, 1061-1067.

Leliott, R. A. \& Dickey, R. S. (1984). Genus VII. Erwinia Winslow, Broadhurst, Buchanan, Krumwiede, Rogers and Smith 1920. In Bergey's Manual of Systematic Bacteriology, vol. 1, pp. 469-476. Edited by N. R. Krieg \& J. G. Holt. Baltimore: Williams \& Wilkins.

Marmur, J. \& Doty, P. (1962). Determination of the base composition of deoxyribonucleic acid from its thermal denaturation temperature. $J \mathrm{Mol}$ Biol 5, 109-118.

Mergaert, J., Verdonck, L., Kersters, K., Swings, J., Boeufgras, J. M. \& De Ley, J. (1984). Numerical taxonomy of Erwinia species using API systems. J Gen Microbiol 130, 1893-1910.

Ngwira, N. \& Samson, R. (1990). Erwinia chrysanthemi: description of two new biovars (bv 8 and 9) isolated from kalanchoe and maize host plants. Agronomie 10, 341-345.

Owen, R. J. \& Lapage, S. P. (1976). The thermal denaturation of partly purified bacterial deoxyribonucleic acid and its taxonomic implications. J Appl Bacteriol 41, 335-340.

Patel, M. K., Kulkarni, Y. S. \& Dhande, G. W. (1952). Some new bacterial diseases of plants. Curr Sci 12, 345-346.

Perrière, G. \& Gouy, M. (1996). WWW-Query: an on-line retrieval system for biological sequence banks. Biochimie 78, 364-369.

Samson, R., Poutier, F., Sailly, M. \& Jouan, B. (1987). Caractérisation des Erwinia chrysanthemi isolées de Solanum tuberosum et d'autres plantes hôtes selon les biovars et sérogroupes. EPPO Bull 17, 11-16.

Slowinski, J. B. \& Page, R. D. (1999). How should species phylogenies be inferred from sequence data. Syst Biol 48, 814-825.

Smibert, R. M. \& Krieg, N. R. (1994). Phenotypic characterization. 
In Methods for General and Molecular Bacteriology, pp. 607-654. Edited by P. Gerhardt, R. G. E. Murray, W. A. Wood \& N. R. Krieg. Washington, DC: American Society for Microbiology.

Sneath, P. H. A. \& Sokal, R. R. (1973). Numerical Taxonomy: the Principles and Practice of Numerical Classification. San Francisco: Freeman.

Spröer, C., Mendrock, U., Swiderski, J., Lang, E. \& Stackebrandt, E. (1999). The phylogenetic position of Serratia, Buttauxiella and some other genera of the family Enterobacteriaceae. Int $J$ Syst Bacteriol 49, 1433-1438.

Sutra, L., Prior, P., Perlemoine, K., Risède, J. M., Cao-Van, P. \& Gardan, L. (1999). Description of a new disease on Erythrina sp. in Martinique (French West Indies) and preliminary characterization of the causal agent as a novel Erwinia species. Plant Pathol 48, 253-259.

Verdonck, L., Mergaert, J., Rijckaert, C., Swings, J., Kersters, K. \& De Ley, J. (1987). Genus Erwinia: numerical analysis of phenotypic features. Int J Syst Bacteriol 37, 4-18.

Weisburg, W. G., Barns, S. M., Pelletier, D. A. \& Lane, D. J. (1991). $16 \mathrm{~S}$ ribosomal DNA amplification for phylogenic study. $J$ Bacteriol 173, 697-703.

Young, J. M., Saddler, G. S., Takikawa, Y., De Boer, S. H., Vauterin, L., Gardan, L., Gvozdyak, R. I. \& Stead, D. (1996). Names of plant pathogenic bacteria 1864-1995. Rev Plant Pathol 75, 721-863. 